\title{
CONFORMITY BEHIND THE SOCIAL AND SPATIAL SEGREGATION IN SUB-URBAN AREA A CASE AT GADING SERPONG NEW TOWN, TANGERANG
}

\author{
Mohammad Ischak ${ }^{1}$, Bambang Setioko ${ }^{2}$, Dedes Nurgandarum ${ }^{3}$
}

Diterima: March $8^{\text {th }} 2019$ Disetujui: May 25 2019

\begin{abstract}
The phenomenon of urban growth in rural areas created sub-urban areas like Tangerang region. Occupancy of space created by planned settlement against unplanned settlement raises spatial and social segregation. Previous studies have shown more on the negative side of the collision phenomenon with the point of view of the occurrence of physical and social unconformity between the newcomers as residents of planned settlements with the natives. On the other hand, it turns out that unplanned settlements still exist, thus raising the question of research is there conformity in the point of view of unplanned settlement settlers? To get an answer to the question, this research used analytical descriptive method, where data obtained directly from the field through observation and in-depth interviews with unplanned settlement settlers. The result of the analysis showed that although the spatial and social segregation is apparent, the community of unplanned settlers does not feel disturbed and the daily social economic activity of the community keeps going well, even the quality of life improves in some points. Such conditions create a form of internal conformity with parameters formulated by the community, including access to and from unplanned settlements, integrated infrastructures, open access to economic activities, and still guaranteed socio-cultural activities.
\end{abstract}

Keywords: comformity, segregation, unplanned settlements

\section{INTRODUCTION}

The growth of big and medium cities in almost all over the world is a fact happening today and is believed to progressively continue in the future (UN Habitat III, 2017). Urbanization becomes the main factor that makes big cities lack of land that support their capacity to fulfill occupancy requirement for their increasing population (UN DESA, 2014). Due to the limited land within the cities, their growth then leads to increasing of urban fringe throughout the world both in number and typology, and their growth is heavily dependent on local economic and socio-economic conditions (UN Habitat, 2013).

The growth of cities into rural areas creates special areas known as urban or suburban areas that have special characters, such as typical spatial configurations (Moreira, F.,et.al., 2016). This areas is a complex mechanism that contains the sociological, political, legal, economic or suburban environment (Pozoukidou, G., \& Ntriankos, I., 2017). These areas have a distinctive character in which we can still find agricultural land in the environment having characters as a city (Sauri , D., et.al., 2011). The mechanisms and processes of sub-urban growth involve government intervention (Damayanti, 2010; Thorn,

\footnotetext{
${ }^{1}$ Engineering Faculty of Civil and Planning, University of Trisakti

${ }^{2}$ Department of Architecture/Universitas Diponegoro

${ }^{3}$ Department of Architecture/University of Trisakti
} 
J., et.al., 2015; Tian, L., et.al., 2016; Chitrakar, M., et .al., 2016) and are left to market mechanisms so that they are fully handled by the private sector, in this case the housing developers and the new city developers (Diningrat, 2014; Duren, NRL, 2018) The growth of the city towards the periphery becomes a certainty that will inevitably happen especially in the city large in developing countries and have a positive influence to promote and prosper the community in the form of road infrastructure development connecting the city centers or to other cities; hence trigerring the economic growth of the region and the development of the previously rural areas into urban or sub-urban areas (Sujarto, 1993; Sieverts, 2003; Soetomo, 2003; Nas, 2005).

Besides bringing the positive impacts, the encounter of urban and rural characters in a sub-urban area has also caused a negative impact in which the spatial development becomes uncontrolled which eventually increases number of people who lost land and decreases the quality of life (Gebregziabher, Z., et.al., 2014, Bagheri, B., Tousi, S.N., 2018), management conflicts (Zhao, P., et.al., 2009), ecological changes and decline (Haregeweyn, N., et.al., 2012; Dupras, J., et.al., 2016; Parvaiz A. et al., 2017; Dadi, D., et al, 2016), are the most obvious phenomena the occurrence of social and spatial segregation between indigenous and migrant populations occupying these new environments, which are in the form of gated and guarded communities (Firman, T., 2009; Tedong, P.A.,et.al., 2014; Winarso, et.al.,2015; Daskalova, D. \& D. Slaev, DA, 2015; Noorloos, F. \& Steel, G., 2016; Cordova, GF., et.al., 2016; Borsdorf, A., et.al., 2016; Michelini, J.J., Pintos, P., 2016).

In the context of urban expansion into rural areas, so far the existing researches have only seen more negative sides of segregation and losses of native people as early inhabitants of rural areas. This condition raises the question "Does the segregation in the sub-urban area have only negative effects on the communities affected by urban expansion? The next question is "How do rural indigenous people respond to the occurrence of such segregation? To answer these research questions, this paper aims to see the problem more objectively by using sustainable development approach in the context of the growth of sub-urban areas. Meanwhile, to obtain data in the form of community responses to the occurrence of social and spatial segregation around the neighborhood where live, studied with the parameters of quality of life.

A study that examines the relevance of suburban growth with the concept of a sustainable development approach becomes one of the main topics of current researchers. As an illustration, Geneletti, D., et al., (2017) reviewed a total of 102 papers reviewing the linkages of sub-urban growth with sustainable development with the surprising conclusion that the sustainable development formula was not focused on sub-urban growth studies because UN Habitat formulates sustainable urban development for the wider city context. Thus there is still an opportunity to conduct a study on the possibility of implementing sustainable development in the context of sub-urban growth both in the context of planning, design, and management. (Editors of LUP Journals, 2017). This fact is reinforced by the Quito declaration that emphasizes the development of a city should hold the principle of sustainability in which there are social and economic parameters (UN Habitat III, 2017).

Related to the phenomenon of spatial and social segregation in the sub-urban areas as the impact of urban character expansion into rural areas, the native people, who are basically influenced by this phenomenon both in the context of individuals and communities, have two options: to stay in their own area that is experiencing changes or to leave and move to further areas due to lack of bargaining power. These conditions currently happen and become a macro phenomenon in the research location, namely the area of Serpong which has become the new city of Gading Serpong. The community's response to the expansion undertaken by the developers has created distinctive morphology of the region; that is, there are many indigenous settlements in the new town 
of Gading Serpong as a result of the choice made the native people of this area to survive (Ischak, M., et.al., 2018).

This research does not aim to examine the concept of sustainable development on the development of the new city area of Gading Serpong, but it emphasizes the study of the residents condition in responding to the rapid changes and development of the surrounding environment that change the overall environment around the residence visually indicated by the occurrence of social and spatial segregation. With the existence of enclave settlements, it indicates that the residents still feel satisfied and comfortable both in the micro and macro environment although there are spatial and social restrictions around it. Thus, the focus of this study is the study of the responses of residents of enclave settlements to the segregation that has occurred due to the existence of the new city of Gading Serpong.

To examine community responses related to their feeling of satisfaction and comfort when living in their environment, the parameters of Quality of life (Bialowolska, DW, 2016), both in the context of individuals, homes, micro and macro environment (Ballas, D., 2013; Marans, RW, 2015) were employed. These parameters include physical and nonphysical components (El Din, et.al., 2013; Ebrahimzadeh, I., et.al., 2016; Bialowolska, D.W., 2016; Suprapti, A., et.al., 2017). Physical components include public space, access to public facilities and social facilities (education, health, religion, entertainment, and markets), and transportation infrastructures; while non-physical components are social equality and economic improvement of the family. The analysis of these components was placed in the context of the relationship between the enclave settlement and the new city. Therefore, the output of this study was the assessment of the alignment or unconformity currently felt by the inhabitants of the enclave settlement against the existence of the new city.

\section{METHODS}

The research was conducted by descriptive-analytical method, where the data obtained directly from the field through observation and in-depth interviews with selected informants and limited questionnaire distribution. The questionnaires were aimed only to the residents who living in the locusl of the research. Physical and non-physical data in the form of phenomena and residents' activities then were systemized in life quality parameters in comparison with the sustainable development parameter as the base of analysis. The life quality parameter was derived as the essence of theory and reference. In general, this research is based on the scheme (figure 1) below.

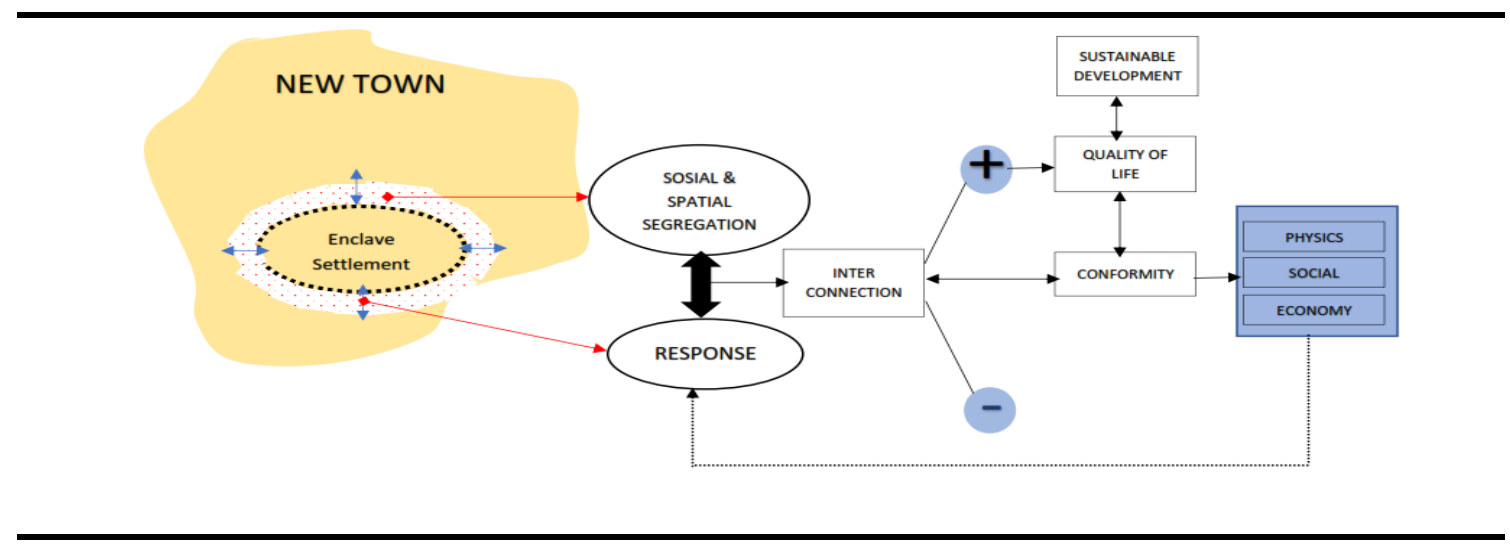

Figure 1. The Research Scheme 


\section{DISCUSSION}

Analysis of the data and research problems in the field begun with observing the segregation and its potential that will or has occurred. Segregation and the chances of segregation that occur later are associated with interrelatedness between the enclave settlement and the new settlement expressed through the new town. The analysis is based on the way the community of enclave settlement perceives and responds to environmental changes due to the emergence of new towns around the settlement.

\section{Segregation}

Segregation occurring at the research locus appears in two broadly observable forms: spatial segregation, and social segregation. Spatial segregation occurs in two forms of separation of enclave settlements; namely, the gated and guarded community (figure 2), and the construction of 2-4 metres guardrails (figure 3). Both of these markers are very strong evidence that in the location of the research there is very strong spatial segregation. Even the impression that appears is that the original settlement is the one in the middle of a new city area. These conditions have risen the term "the enclave settlement".

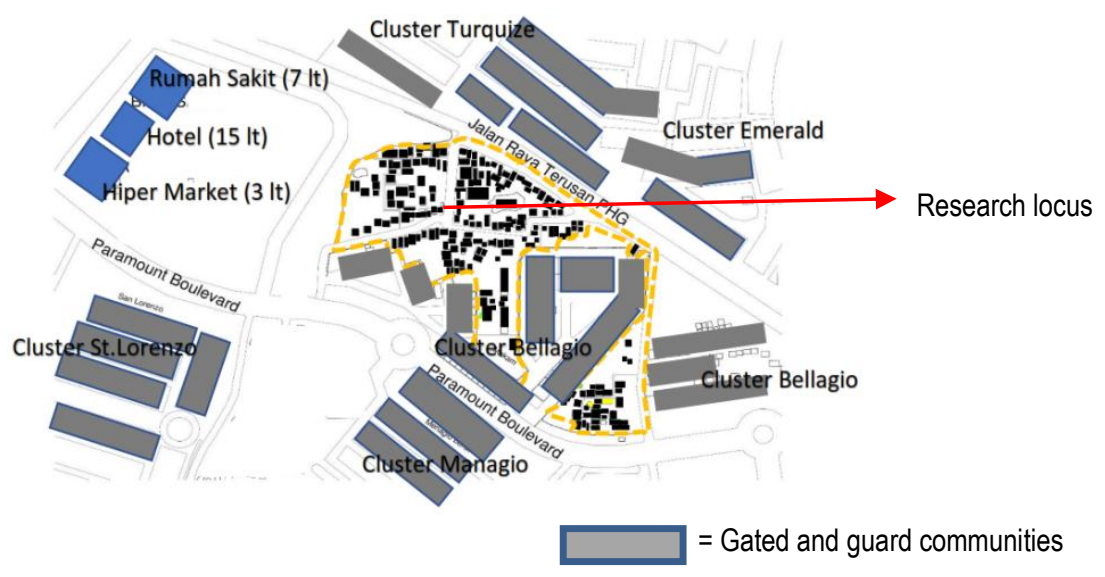

Source : The Research Field, 2017

Figure 2 : The Gated and Guarded Communities around the Research Locus

The occurrence of social segregation is not only proved by the existence of gated and guarded communities in the form of housing clusters for high-income residents, but it is also indicated by the territorial matters. Currently Emerald and Bellagio housing clusters are proposing a separation plan previously included in the Rukun Warga (Community Unit) 06 territory wishing to separate themselves by forming their own RWs. Another phenomenon that occurs is that the existence of a closed new housing clusters that makes public facilities such as playgrounds and access roads cannot be used by the people who live in the study locus because it is only limited by residents of housing clusters. These facts clearly prove that there has been social segregation between old settlements and new settlements that are part of the Gading Serpong area. 


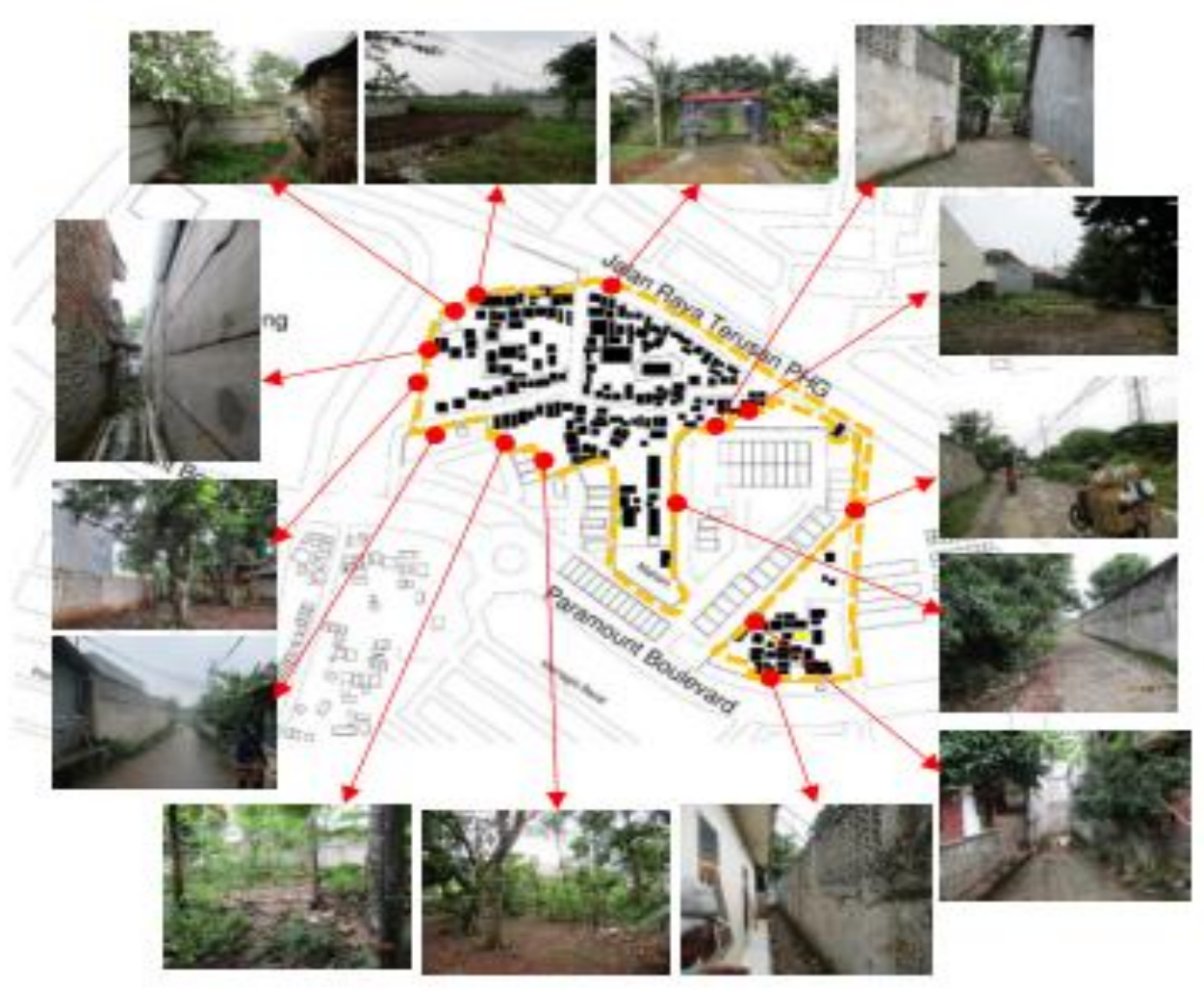

Source : The Research Field, 2017

Figure 3: The Guardrail around the Research Locus

\section{Ongoing Relationship}

Although the data collected from the field indicated the presence of spatial and social segregation as described earlier, it turns out that there are other data showing the relationship between old settlements and new settlements. This kind of relationship is related to physical and non-physical terms. Relationships in the physical term include infrastructures like access, sewers and roads while non-physical relationships include social and economic relations. Although municipal developers built guardrails along the border of the old settlement area, they still provide access in the form of a road connection to the old settlement with the main roads built by the developer as the part of the new city infrastructure of Gading Serpong.

The existence of access in and out of this village becomes one of the factors that causes the residents of the research location feel not completely isolated due to the dividing wall by the developer because it can still carry out any activity inside and outside the settlement without any constraints. The presence of access to the Sangereng Curug village which is the location of the study case 1 cannot be separated from the existence of the circulation path outside of the village; that is, the main road was designed by the developer, so the access of settlements enclave to public facilities and social facilities for health, worship, education, and entertainment needs are not constrained. In addition, based on the reconstruction of in-depth interviews with informants, it was found that the main roads and access to settlements (settlements) were the previous roads before the village area was separated due to land acquisition by the developers. Thus emotionally and 
psychologically, the residents of the settlements at the location of case 1 feel familiar and very familiar with the road conditions and access to the existing village because it does not extremely change the position and the role of the road. Under these conditions, despite spatial and social segregation, the settlement enclave residents feel comfortable to live. Thus, although physically there has been segregation, but the residents of the settlements actually feel the harmony with the presence of the new city of Gading Serpong.

Despite the social segregation, there is a social phenomenon indicating that there is still a social relationship between enclave settlements and new settlements in the form of financial support from new settlement residents if the old settlement residents hold mass events such as commemorations of religious holidays and national celebrations. Another form of social relationship is the community of settlements enclave are still free to hold mass events either religious or private by using loudspeakers without any complaints or protests from developers and residents of new settlements. By examining the condition, it can be concluded that although social segregation occurs, the inhabitants of the enclave settlement still feel comfortable to live and not question the existing social segregation. Thus, the inhabitants of the settlement actually feel the harmony with the presence of the new city of Gading Serpong.

Economics: The relationship in the economic context between enclave settlements and the surrounding new settlements that are part of the new city is a mutually beneficial, and it occurs in two forms, direct and indirect relations. The direct link is the job opportunities provided by the new city to the residents of the enclave settlements. The types of occupations are formal and non-formal jobs. Formal jobs are office stafss and shopkeepers (commercial) while non-formal jobs are parking staffs and traders. From the survey involving 50 families of inhabitants of enclave settlements, 13 of them (26\%) had family members working in the new city zone. Thus the existence of a new city has a direct impact that is felt beneficial by the inhabitants of enclave settlements. Indirect relationship is the business opportunity obtained by the residents of enclave settlements caused by the needs or potential markets created by activities of the people (employees, owners, and visitors) located in the new city area. There are two economic opportunities utilized by residents of enclave settlements namely internal economic opportunities and external economic opportunities. The internal economic opportunity is an economic opportunity caused by the needs of the residents of the kampong settlements, so the scale and target of its these economic activities is inside the village. On the other hand, the external economic opportunity is the economic opportunities caused by human needs that are not limited to the inhabitants of the settlement. Both types of economic opportunities create different building functions (Table 1). The functions of the buildings are architecturally divided into two forms. First, the building is indeed from the beginning designed as a business place, such as food stalls and workshops. Second, it is actually a residence in which it is used terrace as a place for business activities. The distribution of buildings for economic activities can be seen in figure 4 .

Table 1. The Economic Activities and the Building Function Conducted by the Community

\begin{tabular}{|c|c|c|c|c|}
\hline No & $\begin{array}{l}\text { Economic } \\
\text { Opportunities }\end{array}$ & Building Functions & Amount & Total \\
\hline \multirow[t]{7}{*}{1.} & Internal & 1. Grocery stalls & 5 & \\
\hline & & 2. Cellular and internet data stalls & 11 & \\
\hline & & 3. Snack stalls & 14 & \\
\hline & & 4. Food stores & 5 & \\
\hline & & 5. Green groceries & 2 & \\
\hline & & 6. Sewer / tailor & 2 & \\
\hline & & 7. Building material store & 2 & 41 \\
\hline
\end{tabular}




\begin{tabular}{|c|c|c|c|c|}
\hline No & $\begin{array}{l}\text { Economic } \\
\text { Opportunities }\end{array}$ & Building Functions & Amount & Total \\
\hline \multirow[t]{2}{*}{2} & External & 1. Food stores & 3 & \\
\hline & & $\begin{array}{l}\text { 2. Car service and spare parts shops } \\
\text { 3. Rented house }\end{array}$ & $\begin{array}{r}5 \\
18\end{array}$ & 26 \\
\hline
\end{tabular}

Source : The Research Field, 2018

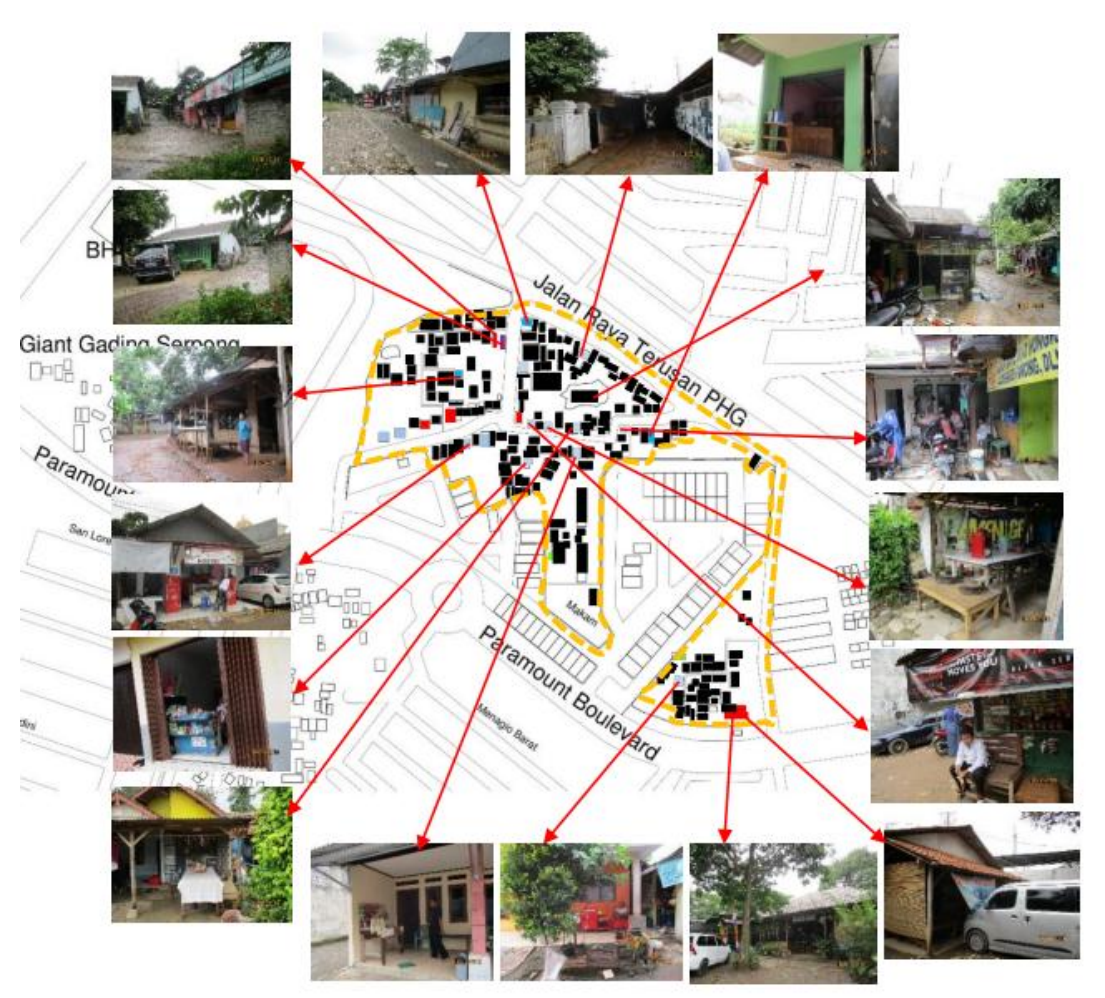

Source : The Research Field, 2017

Figure 4. The Map of Distribution of Business Houses in the Study Area

The phenomenon that characterizes the relationship between settlement in the locus of the study and the new town is the emergence of external opportunities. It can be seen that the location of the village has the advantage because of the proximity to the new town area. Although the location of this kampong has limited access, the changes in the surrounding environment have an effect, either directly or indirectly to the economy of the inhabitants of enclave settlements due to the new functions of the entry to the vicinity. Direct influences include the need for formal employees in new settlements (commerce, services, and offices) to small food stalls. The emergence of new activity centers in urban areas invites formal and non-formal workers who need low-cost rented houses, so the emergence of rented houses is the reflection of the economic relationship between the new city and the enclave settlements. Among the many business buildings organized by the residents, the most prominent ones in both the number and appearance are the rented houses. As illustrated in Table 1, there are 18 buildings owned by the residents having rooms nearly 200.

Physically, the buildings of a rented house are semi-permanent and permanent buildings. The physical difference of the both buildings is related to the rental price and the 
segmentation. The semi-permanent buildings provide less expensive price rent and are occupied by infformal workers such as builders and traveling traders who work in the new City Zone while the permanent ones are more luxurious and expensive because they are intended for formal workers who work in the offices or commercial districs in the new city area. The existence of these rented houses also creates business opportunities for residents of the enclave settlements because most of tenants are family, so they can serve these tenants' needs related to clothing and food. This condition is the reason why many of these residents open green groceries, food stalls, and shops.

The reciprocal relationship that occurs then forms an economic cycle that at the end benefit all parties. Thus, if observed from the side of the economic activities of the inhabitants, the economic cycle that occurs brings benefits that could not be obtained before the arrival of a new town. In the context of segregation, such conditions should be included in the category of social segregation, where the enclave settlements are the area that accommodates the low-income workers while the highly paid workers class is accommodated by the housing provided by the new town developer, both in housing clusters and in apartment. Thus, there is in fact an opportunity to integrate the segregation between the new settlements and the old settlements (Cordova, G.F., et.al., 2016; Critelli, G., \& Musella, M., 2016).

The conditions related to the context of economic cycles is a component that contributes to the life quality for the residents of the enclave settlements. In the next stage it can be concluded that behind the social and spatial segregation that occurs actually, there is actually alignment directly felt by the residents of enclave settlements.

\section{CONCLUSION}

The growth of metropolitan cities like Jakarta that reaches to the outskirts areas of the city is very fast. One form of this urban expansion is the emergence of new towns, such as the new town of Gading Serpong in Tangerang. The presence of these new towns in the areas previously belonged to the rural category has made these areas to be sub-urbans. This regional transformation has caused both spatial and social segregation between new settlements and old settlements that still exists within new town areas.

From the research that has been done, it is concluded that behind the phenomenon of social and spatial segregation, the inhabitants of the old settlements actually get a lot of advantages and feel comfortable in their daily life both socially and economically, so until now most of the residents of old settlements are not disturbed by both social and spatial segregation. The old settlement inhabitants actually respond the seggregation with adjustment through the modification of the use of space by changing their residential buildings into buildings that accommodate their economic activities. Thus, it can be understood that behind the phenomenon of the segregation occuring in this sub-urban area, it turns out that the native community actually live in harmony with the newcomers who stay in the new city area, Gading Serpong.

\section{REFERENCES}

Bagheri B, Tousi SN. (2018). An explanation of urban sprawl phenomenon in Shiraz Metropolitan Area (SMA). Cities, 73, 71-90.

Ballas, D. (2013). What makes a 'happy city'?. Cities, 32, S39-S50.

Bialowolska, DW. (2016). Quality of life in cities - Empirical evidence in comparative European perspective. Cities, 58, 87-96.

Borsdorf A, Hildalgo R, Koppmann SV. (2016). Social segregation and gated communities in Santiago de Chile and Buenos Aires. A comparison, Habitat International, 54, 18 - 27. 
Chitrakar, MR, Baker CD, Guaralda M. (2016). Urban growth and development of contemporary neighbourhood public space in Kathmandu Valley, Nepal. Habitat International, 53, 30-38.

Cordova GF, Maldonado AMF, Pozo JM. (2016). Recent changes in the patterns of socio-spatial segregation in Metropolitan Lima. Habitat International, 54, 28 - 39.

Dadi D, Azadi H, Senbeta F, Abebe K, Stellmacher T, Taheri F. (2016). Urban sprawl and its impacts on land use change in Central Ethiopia. Urban Forestry \& Urban Greening, 16, 132-141.

Damayanti, R. (2010). Pertumbuhan Fisik Kota Karena Pengaruh Industrialisasi, studi kasus kota Ahmedabad India, Seminar Nasional Riset Arsitektur dan Perencanaan (SERAP) 1 : Humanisme, Arsitektur, dan Perencanaan. Yogyakarta: Jurusan Teknik Arsitektur dan Perencanaan Universitas Gadjah Mada.

Daskalova D, Slaev DA. (2015). Diversity in the suburbs: Socio-spatial segregation and mix in post-socialist Sofia, Habitat International, 50, 42 - 50.

Diningrat, RA. (2014). Ketergantungan Kota Baru Kota Harapan Indah terhadap Kota Jakarta dan Wilayah Sekitarnya. Jurnal Perencanaan Wilayah dan Kota ITB, 25(3). 192-212.

Dupras J, Marull J, Parcerisas L, Coll F, Gonzalez A, Girard M, Tello E. (2016). The impacts of urban sprawl on ecological connectivity in the Montreal Metropolitan Region. Environmental Science \& Policy, 58, 61-73.

Duren, NRL. (2018). Why there? Developers' rationale for building social housing in the urban periphery in Latin America. Cities, 72, 411-420.

Ebrahimzadeh I, Shahraki AA, Shahnaz AA, Myandoab AM. (2016). Progressing urban development and life quality simultaneously. City, Culture and Society, 7, 186 - 193.

Editors of LUP Journals. (2017). Editorial: Special issue on sustainable planning approaches for urban peripheries. Landscape and Urban Planning, 165, 172-176.

El Din HS, Shalaby A, Farouh HE, Elariane SA. (2013). Principles of urban quality of life for a neighbourhood. Housing and Building Researh Center Journal, 9, 86-92.

Firman, T. (2009). The continuity and change in mega-urbanization in Indonesia: A survey of Jakarta-Bandung Region (JBR) development. Habitat International, 33, 327-339.

Gebregziabher Z, Yiadom KS, Asfaw M. (2014). The Impact of Urban Sprawl on the Livelihood of Fringe Farmers in Mekelle, Ethiopia. Research on Humanities and Social Sciences, 4(16).

Geneletti D, La Rosa D, Spyra M, Cortinovis C. (2017). A review of approaches and challenges for sustainable planning in urban peripheries. Landscape and Urban Planning, 165, 231-243.

Giuseppe Critelli G, Musella M. (2016). Social Segregation in Urban Area: the results of a project in the metropolitan city of Reggio Calabria. Procedia - Social and Behavioral Sciences, 223, 89-94.

Haregeweyn N, Fikadu G, Tsunekawa A, Tsubo M, Meshesha DT. (2012). The dynamics of urban expansion and its impacts on land use / land cover change and small-scale farmers living near the urban fringe: A case study of Bahir Dar, Ethiopia. Landscape and Urban Planning, 106, 149157.

Ischak M, Setioko B, Gandarum DN. (2018). Design integration of new town development among different developers and with surrounding areas in respect of sustainable development concept. IOP Conferences Series : Earth and Environmental Science, volume 106.

Marans, RW. (2015). Quality of urban life \& environmental sustainability studies: Future linkage opportunities. Habitat International, 45, 47-52.

Michelini JJ, Pintos P. (2016). Metropolitan expansion and new socio-spatial segregation scenarios in contemporary Argentina. The case of Nordelta-Las Tunas (Buenos Aires). Habitat International, 54, 4049.

Moreira F, Fontes I, Dias S, Silva JB, Ramos IL. (2016). Contrasting static versus dynamic-based typologies of land cover patterns in the Lisbon metropolitan area: Towards a better understanding of peri-urban areas. Applied Geography, 75, 49-59.

Nas, PJM, ed. (2005). Directors of Urban Change in Asia. New York: Roudledge.

Noorloos F, Steel G. (2016). Lifestyle migration and socio-spatial segregation in the urban(izing) landscapes of Cuenca (Ecuador) and Guanacaste (Costa Rica). Habitat International, 54-57.

Parvaiz AB, Shafiq M, Abaas AM, Ahmed P. (2017). Urban sprawl and its impact on landuse/land cover dynamics of Dehradun City, India. International Journal of Sustainable Built Environment, 6, 513-521.

Pozoukidou G, Ntriankos I. (2017). Measuring and assessing urban sprawl: A proposed indicator system for the city of Thessaloniki, Greece. Remote Sensing Applications: Society and Environment, 8, 30-40. 
Sauri D, Serra P, Modugno S, Seifolddini F, Pourahmad A. (2011). Urban sprawl pattern and land-use change detection in Yazd, Iran. Habitat International, 35, 521- 528.

Sieverts, T. (2003). Cities Without Cities, London: Spon Press.

Soetomo, S. (2002). Strategi Desain Ruang Sub-Urban dalam Menopang Pembangunan yang Berkelanjutan Menuju Ruang yang Beragam dari Pedesaan ke Perkotaan. Pidato Pengukuhan Guru Besar pada Fakultas Teknik Universitas Diponegoro.

Sujarto, D. (1993). Perkembangan Kota Baru, Jurnal Telaah Planologi ITB, 9 September, Bandung.

Suprapti A, Kistanto NH, Pandelaki EE, Indrosaptono J. (2017). Control of Spatial protection in Kauman Semarang, Jornal of Architecture and Urbanism, 41(4), 268-277.

Tedong PA, Grant JL, Aziz WNA. (2014). The social and spatial implications of community action to enclose space: Guarded neighbourhoods in Selangor, Malaysia. Cities, 41, 30-37.

Thorn J, Thomas FT, Helfgott A. (2015). Autonomous adaptation to global environmental change in periurban settlements: Evidence of a growing culture of innovation and revitalisation In Mathare Valley Slums, Nairobi. Global Environmental Change, 31, 121-131.

Tian L, Biqing G, Yongfu L, (2016). Cities Impacts of state-led and bottom-up urbanization on land use change in the peri-urban areas of Shanghai: Planned growth or uncontrolled sprawl?. Cities published by Elsevier.

UN Habitat III. (2017). New Urban Agenda, Housing and Sustainable Urban Development, Quito, (Habitat III).

United Nations, Department of Economic and Sosial Affairs, Population Division 2014 World Urbanization Prospects: The 2014 Revision, Highlights, United Nation, New York.

UN-Habitat. (2013). State of the world's cities 2012/2013: Prosperity of cities. Nairobi : UN-Habitat.

Winarso H, Hudalah D, Firman T. (2015). Peri-urban transformation in the Jakarta metropolitan area. Habitat International, 49, 221-229.

Zhao P, Lu B, Woltjer J. (2009). Conflicts in urban fringe in the transformation era: An examination of performance of the metropolitan growth management in Beijing. Habitat International, 33, 347-356. 